\title{
THE PROSE DISCOURSE OF UKRAINIAN LITERATURE OF THE LATE 18TH TO MID-19TH CENTURIES: THE PROBLEM OF CANON FORMATION
}

\section{Chyk D. Ch.}

\section{INTRODUCTION}

The literary canon is still often interpreted as a definite list of norms that "push" the works that lack certain invariable aesthetic features from the top of the literary process. The list of "eternal" and "ingenious" works, which is inherent in almost all national literatures, is proclaimed inviolable - overcoming this constancy is often helped by the change of ideological or aesthetic paradigms, personal preferences of the researcher or even the literary studies' or textbooks' volume that "automatically" cross out certain surnames.

In his literary bestseller "The Western Canon: The Books and School of the Ages" (the 1st ed. - 1994) an American literary critic Harold Bloom, developing his own Western literatures canon scheme, transferred an Italian philosopher Giambattista Vico's idea about the three main stages of the nation development (theocratic, aristocratic, democratic) on the world literary process ${ }^{1}$. It is clear that Bloom's mythological scheme of William Shakespeare's "sacralisation" reflects in some way the subjective aesthetic sympathies of the author, which, if one change their perspective, methodology and central persona, can also be reasonably revised. For example, due to a Ukrainian scholar Borys Shalaginov, Johann W. von Goethe and his "Faust. Eine Tragödie" ("Faust: Tragedy") replaced Shakespeare's post-medieval era, and formed the "heart" of the New European canon. The basis for the German writer's centering is his proclamation of the art's exceptional importance, the emergence of a modern life understanding, the mythological thinking foundation of the

${ }^{1}$ Блум Г. Західний канон: книги на тлі епох / пер. 3 англ. під заг. ред. Р. Семківа. Київ : Факт, 2007. С. 5-6. 
modern era and the perception of man as a culture creator ${ }^{2}$. However, in the case of the colonized peoples' literatures, in particular the Ukrainian one, the civilizational concept of Vico, capable in general for most Western European and American literatures, in Bloom's interpretation (with an emphasis on creative aesthetism) needs at least reconsideration. For example, the "extra" era in the literature history can be called colonial and in the nominal "scheme due to Vico" it will take the place of the democratic epoch after the aristocratic one.

The Ukrainian literature in its current canon format requires a thorough revision and detachment of a considerable number of outdated views and stereotypes that have been inherited from Soviet literary studies $^{3}$. In addition, the canon of the history of Ukrainian literature is often regarded as one that should present exclusively Ukrainian-language pieces of fiction that embody national identity. As a consequence, a large number of works written in Russian, Polish or other languages are ignored, which, I believe, can be counted as elements of two or more canons at the same time due to the author's language usage, or writers who are rejected ex cathedra for one reason or another (they had to leave their homeland and sought after self-realization ways in the metropolis (the reasons might be different - education, civil or military career, the search for writer's glory, etc.) and had since then been territorially tied to a foreign country, creating its, but also and their own cultural product).

\section{The problem of literary identification of Ukrainian Russian-writing writers}

The age-old problem of Ukrainian literary criticism is the issue of literary (self-)identification of Ukrainian Russian-writing writers of the $1^{\text {st }}$ half and mid-19th centuries. I should first mention Vasyl Kapnist, Vasyl Narizhny, Pavlo Biletsky-Nosenko, Orest Somov, Alexander Perovsky (Antoniy Pogorelsky), Ivan Kulzhinsky, and, of course, Mykola Gogol

2 Шалагінов Б. «Фауст» Й. В. Гете як центр новоєвропейського літературного канону // Б. Шалагінов. Класики і романтики: Штудії з історії німецької літератури XVIII - XIX століть. Київ : Києво-Могилянська академія, 2013. С. 47-48.

3 Александрова Г. Глобалізація i нові стратегії в компаративістиці // Українознавчий альманах. 2013. Вип. 11. С. 79. 
(I have to mention here and such bilingual writers, as Yevhen Grebinka, Grygoriy Kvitka (Grytsko Osnovyanenko) and Taras Shevchenko) and others. Getting higher education in the capital's institutions, working in the imperial state system (in its civilian or military dimensions), and often forced usage of the Russian language in literary creativity, have prompted many critics to consider these authors' achievements in the context of Russian literature, while being "distinctly different" from the Ukrainian literature. After all, the prospect of considering Ukraine as a self-sufficient state (in those times it was a colony of the Austrian and Russian empires) with its own people and, accordingly, linguistic, cultural, historical traditions and peculiarities, is now constantly being questioned.

If the researcher follows the pro-imperial logic, it should be noted that almost all the writers who worked in Ukraine before 1917 he must regard as mainly Russian and Austrian authors. This difficult issue is already being attempted to solve, at least theoretically, by contemporary literary critics. The opinion of an Ukrainian researcher Oleksandr Glotov, who offers along with the main parameters of determining the literary affiliation of a writer and the option of including the works written in Russian through objective historical circumstances in the history of Ukrainian literature, is noteworthy ${ }^{4}$ (the list can be continued: Hebrew, German, Polish works, etc.). The creation of the "great" history of Ukrainian literature, proposed by the researcher, provides the parallel entry of the texts mentioned into other canons. It is often the language marker that has become a barrier to this approach.

After the state forbid on Ukrainian-language bookselling and the liquidation of the Cossack Hetmanate in the 18th cent., the Russian language became the dominant language of high Ukrainian culture. Therefore, even those texts of the first decades of the 19th century which were "subversive" to imperial discourse, like an anonymous "Istoriya Rusov, ili Maloy Rosii" ("History of Ruthenians or Little Russia"), were written in Russian. During this period, the Little Russian elite had already formed, which, with an amazing ability, combined Russian royalism with Ukrainian nobility, thus creating a new degree of its own consciousness.

4 Глотов О. Російська література України: методологія питання // Теорія літератури. Компаративістика. Україністика: зб. наук. праць 3 нагоди 70-річчя професора Романа Гром’яка // Studia methodologica. 2007. Вип. 19. С. 30. 
The elite also used the newly created Russian literary language, which at that time completely replaced the old Ukrainian language, and instead of Latin the Ukrainian noble studied French - the language of the Russian aristocracy - and adopted the customs of the imperial capital (these metamorphoses in the traditions of the Ukrainian nobility are satirically illustrated by G. Kvitka-Osnovyanenko in his novel "Pan Khaliavsky" ("Lord Khaliavsky")). A modern Canadian historian Zenoviy Kogut writes about the dialectical process of formation of Little Russian identity and its important role in the process of Ukrainian national state building ${ }^{5}$ :

Due to the interest in antiquity and nostalgia for it, the Ukrainian nobility managed to preserve the remains of Little Russian identity until the 1830s and 1840s. At the same time, under the influence of Herder and Romanticism, the next generation discovered the Ukrainian people with its original language ${ }^{6}$.

An illustrative case of the "Russian canonization" specifics is Vasyl Kapnist, a Ukrainian-Russian poet and playwright whose most of his life was connected with Ukraine. Having gained his fame as a writer after the release of a satirical comedy in verse "Yabeda" ("The Sneak") (1798), which in the canon of Russian dramaturgy of the 18th century comes immediately after the play "Nedorosl" ("The Minor") (1782) by Denis Fonvizin (von Wiesen), V. Kapnist held the second "honourable" place in the Russian playwrights pantheon until the appearance of "Gore ot uma" ("Woe from Wit") (1825) by Alexander Griboyedov. The litigation of Ukrainian landlords, satirically portrayed in the comedy "The Sneak", would later become the main form of unfolding events in the Ukrainian stories of "Dva Ivana, ili Strast k tyazhbam" ("Two Ivans, or the Passion for Litigation") (1825) by V. Narizhny and "Povest o tom, kak possorilsya Ivan Ivanovich s Ivanom Nikiforovichem" ("The Tale of How Ivan Ivanovich Quarreled with Ivan Nikiforovich”) (1834) by M. Gogol ${ }^{7}$.

${ }^{5}$ In all the excerpts the translation from Ukrainian or Russian is mine unless noted otherwise. - D. Ch.

${ }^{6}$ Когут 3. Розвиток малоросійської самосвідомості і українське національне будівництво // 3. Когут. Коріння ідентичности. Студії з ранньомодерної і модерної історії України. Київ : Критика, 2004. С. 99.

${ }^{7}$ Берков П.Н. История русской комедии XVIII в. Ленинград : Наука, 1977. С, 353. 
The choice of the metropolis language, participation in empire military (service in the army) and noble institutions (V. Kapnist held various elected positions in the Kyiv and Poltava provinces), active literary activity (publication of poetic works in Russian magazines) - all these factors allegedly serve in favor of Kapnist's exclusive affiliation with the Russian literature. However, texts like "The Sneak", which in a disguised form raise the Ukrainian problems, also belong to the Ukrainian literary canon.

I would like to draw the reader's attention to the formation of the Russian literary canon in the 1820s-1830s, which (without taking into account national, cultural and, finally, literary features) contains Ukrainian and Polish writers. It is clear that this approach was primarily in line with imperial interests and ambitions, which needed a fuller appreciation in the arts. An illustrative example is the treatise "On Romantic Poetry" (1823) by the Ukrainian-Russian writer Orest Somov, who without any hesitation refers Ukrainians, Lithuanians, Poles, Tatars, Finns, Caucasians to Russians, emphasizing that the history and culture of these peoples can provide rich material for fictional writing ${ }^{8}$. It was at this time that the discussion was taking place between apologists of Russian and Little Russian literature, the essence of which was to acknowledge or deny the distinctness and self-sufficiency of literature in the Ukrainian language. Often, these disputes moved into the realm of purely artistic texts - like the first Ukrainian-language short story "Saldatsky Patret" ("The Portrait of a Soldier") by G. Kvitka-Osnovyanenko, written with the special purpose of preventing the writer from biased assessment of Russian journalists and literary critics for the first Ukrainian-language novelette "Marusya" or a literary manifesto like "Suplika do pana izdatelya" ("The Announcement to Mr. Publisher") by the same author who upheld the right of Ukrainian literature to exist.

Therefore, the period of functioning of the literature of colonized Ukraine at the end of 18th - the middle of the 19th cent. should be considered in the light of historical features, cultural situation, but without such

8 Сомов О.О романтической поэзии: опыт в трех статьях. Санкт-Петербург : В Тип. Имп. Воспитательнаго Дома, 1823. С. 86-87. 
widespread idea of "romanticized Ukrainian nationalism" in some recent literary works (according to Olena Yurchuk's apt phrase) ${ }^{9}$. Here, in particular, the concept of the nation of American political scientist Benedict Anderson may prove useful. The notion of an "imagined community" as a political and genetically restricted unity whose representatives experience in their minds an image of involvement ${ }^{10}$, allows to characterize more precisely the initial stage of Ukrainian nation formation of the early 19th century within the multiethnic empires mentioned, and which identified itself within the "Little Russian" or "Rusyn" community (in Galicia, for instance, Ukrainian identity was also formed in the struggle - first of all, with Polophilic and partly Russophile tendencies). National patriotism was replaced by regional patriotism, which often existed - paradoxically - in close connection with imperial patriotism.

The above facts does not confirm the complete absence of national patriotism and its hidden (for obvious reasons of self-protection under conditions of totalitarian censorship) manifestations in the diariuszes (diaries) and epistolaries of the Ukrainian elite. As Tamara Gundorova remarks, in the Russian literature of the early 19th century hybridity was inherent, which was to demonstrate a degree of cultural integration into the imperial "body", . However, in the 1820-1830's, most texts of Ukrainian writers encounter the dual language of mimicry inbuilt in cultural hybrids, as representatives of postcolonial criticism, like the American researcher Homi Bhabga, emphasize in their writings.

The Ukrainians were not yet the sole "imagined community" because of the actual lack of political identification, the rudimentary state of ideas of sovereignty and nationalism, the unequivocal interpretation of their own historical and cultural roots. The first attempt to overcome this "Little Russian" duality was made by members of the secret "Slavic Brotherhood of St. Cyril and Methodius", who planned to replace imperial patriotism with Slavic ones. In their programme "Knyha buttia ukrainskoho narodu"

\footnotetext{
${ }^{9}$ Юрчук О.У тіні імперії: українська література у світлі постколоніальної теорії : монографія. Київ : Академія, 2013. С. 19.

10 Андерсон Б. Уявлені спільноти. Міркування щодо походження й поширення націоналізму. Київ : Критика, 2001. С. 22-25.

${ }^{11}$ Гундорова Т. Микола Гоголь і колоніальний кітч // Гоголезнавчі студії. Ніжин, 2009. Вип. 18. С. 25.
} 
("Zakon Bozhyi")" ("The Book of Being of the Ukrainian People" ("The Law of God")) by one of the most famous "brothers" Mykola Kostomarov one can observe manifestations of "primary" nationalism and the search for a theoretical basis for cultural autonomy, on which the national idea would grow much later. In the article "Two Russian Nationalities (A Letter to the Editor)" (1861), declaring the proximity of "Great Russians" and "South Russians" (as opposed to the closeness of Ukrainians and Poles), he put forward a number of arguments on the benefit of the Ukrainian national individuality ${ }^{12}$.

The Ukrainian writers of the 1 st half of the 19th cent. is also an "imagined community" whose members in their literary work saw the national literature development quite differently and often in diametrically opposed paradigms - colonial, imperial or national. Such pluralism of views led to dissimilar linguistic choices, genre orientation, and reception of other European literatures. Exemplary, for instance, are the bilingualism and diversity of the professional activities of G. Kvitka-Osnovyanenko and Ye. Hrebinka, who at the same time actively participated in the creation of Ukrainian and Russian national literatures.

As expected, the creation of a lasting imperial view of colonial Ukraine was partly aided by the writers who presented it in the Russian literature. The attempt to portray Little Russia in a down-to-earth form (as a peripheral wilderness in the "enlightened" empire backyard) was unintended or inadmissible to the generally accepted imperial stereotypes inherent in certain pieces of fiction of Russian-speaking writers who were Ukrainians (then - Little Russians) and served in public or military institutions of the metropolis, for obvious reasons linking their literary progress with the highly cultured "northern capital". Some authors, paradigmatically referring to Russian and Ukrainian literature, simultaneously chose in their works such topoi and concepts that would testify to the conscious choice of imperial ideology.

The most researched and paradoxically controversial is also the problem of the formation of Ukrainian literature in the 1st half of the

12 Костомаров Н. Две русские народности (Письмо к редактору) // Основа. 1861. № 3. C. 33-80. 
19th cent., in particular the genesis and development of a prose genres' system, which attests to all the contradictions of the contemporary literary process. The complex issue of incorporating Ukrainian Russian-language and Ukrainian-language literature into Russian literature is less studied: for understandable and discussed reasons, the "undeniable and irreversible influence" of Russian literature on Ukrainian writers has been largely considered. Even the creativity of 19th-century Ukrainian writers, often written in Russian, was often regarded as an integral part of Russian literature, like the Russian-language works of G. Kvitka-Osnovyanenko and Ye. Hrebinka ${ }^{13}$. This obvious declaration may also serve as a forced "statement", which here acquires an ironic denotative meaning:

"Great Russian literature of the 19th - 20th cent. helped Ukrainian literature to develop, nourished it with advanced ideas, supported it in difficult moments" $"$.

It is clear that the inclusion of V. Narizhny or M. Gogol in the Ukrainian literature was impossible in the works, since the authors were considered exclusively as Russian writers, but a comprehensive study of this issue would give an unbiased modern assessment of UkrainianRussian literary relations.

It should be noted, however, that there is a recent trend of a certain updating of the Ukrainian literature canon, based on new methodological approaches and principles that could be applied in the analysis of other periods. Thus, a modern Italian researcher Giovanna Brogi Bercoff proposes to consider Ukrainian Baroque literature as an independent "canonical" system and part of a wider system that incorporates the canons of neighboring literatures and, even more broadly, the canons of European literatures $^{15}$. After all, the phenomenon of incorporating Ukrainian literature into the literatures of neighboring countries, in particular Russian or Polish, is noticeable in the following centuries; this, after all, is still ongoing in our time. However, some contemporary studies, emphasizing

13 Зубков С. Д. Русская проза Г. Ф. Квитки и Е. П. Гребенки в контексте русскоукраинских литературных связей. Київ : Наук. думка, 1979. 272 с.

${ }^{14}$ Білецький О. І. Гоголь і українська література // Гоголь і українська література XIX ст. : зб. ст. Київ : Держ. в-во худ. літ., 1954. С. 3.

15 Беркофф Дж. Б. Чи існує канон українського літературного Бароко? // Український гуманітарний огляд. 2012. Вип. 16-17. С. 13. 
the dominance of a purely national issue of a writer's work, removing pieces of fiction from a non-literary context, "place" them in a sterile and closed dimension for other literatures.

I'll briefly outline some planes for the creation of the term "canon". Jan Assmann convincingly puts in the semantic field of this term the invariance category, which implies the presence of points of support, equality, accuracy. Invariance is a kind of "sanctification" that secures the "inviolability" of a work of art. Being legal and authoritative, the canon, in the context of changing traditions, aims to present compulsory rules and regulations. It also provides for polarization, a clear delineation between elitist and mass literature. Jan Assman, as one of the authors of the concept of collective memory, defines the canon as a stabilizer of the collective consciousness, which at the same time presents the personal ${ }^{16}$.

It is clear that the problem of the formation of national literatures in the context of colonization is relevant to many postcolonial literary studies and requires methodological approaches that would not restrict the inclusion of authors in the canons and would not unjustifiably expand it. Marko Pavlyshyn sees the restriction of the canon of Ukrainian literature in the type of recipient, to whom representatives of a "narrow" canon (representatives of an ethno-cultural nation) are oriented. Provided that the reader is being reoriented to represent the civic nation, the canon works will not represent exclusively the ethno-national narrative discourse ${ }^{17}$. The researcher points out that with regard to Ukrainian literature of the 1st half of the 19th cent. one should always bear in mind its ethnocultural multifacetedness, which is also characteristic of subsequent periods. Expressing only the Ukrainian narrative is not only detrimental to the complete study of this peculiarity, but also specific manipulation for the sake of realizing the complex of the "little brother".

16 Ассман Ян. Культурная память: Письмо, память о прошлом и политическая идентичность в высоких культурах древности / пер. с нем. М. М. Сокольской. Москва : Языки славянской культуры, 2004. С. 130-138.

${ }^{17}$ Павлишин М. Історія літератури і здоровий глузд // Історії літератури : збірник статей / упоряд. О. Галета, Є. Гулевич, 3. Рибчинська (Центр гуманітарних досліджень ЛНУ ім. Івана Франка). Київ : Смолоскип ; Львів : Літопис, 2010. С. 21. 


\section{Ukrainian literature of the 19th cent.: new research perspective for studying}

One of the most productive new research perspectives for studying Ukrainian literature of the 19th cent. I consider to be is the one projected by a contemporary Kazakh researcher Nurbolat Dzhuanishbekov. For the analysis of Kazakh literature of the era of socialist realism, he proposes a theory of integrative literature that can be applied to studying of other colonial-period literatures like the Ukrainian one. N. Dzhunyshbekov understands integrative literature as a special form of synthesis of literature and other forms of social consciousnesses, which, as a result, constitutes "frontier" synthesized literature with its distinct typological features. In such literature the scientist recommends to distinguish the following typological groups depending on the level of integration: adaptive, differential, convergentive, biliterary, and assimilative $^{18}$. I'll consider the Ukrainian literature of the late 18th to mid19th centuries, using this classification.

In the first group - the adaptive one - there are writers who, in various forms of reception (mainly adaptation and translation), represent inter-literary connections (Ivan Kotlyarevsky, Petro Gulak-Artemovsky, Leonid Glibov). The works of these writers are usually written in their own language, like the mock-heroic poem by I. Kotlyarevsky "Eneyida" ("Aeneid"), whose intertextual background is extremely rich. In among the European "Aeneids" the literary work of I. Kotlyarevsky holds the first place of honor. The writer created an alternative and foreign-language project of colonized literature within the imperial baroque literature (this tradition was later successfully destroyed by T. Shevchenko). The originality of the idea served as a catalyst for a large number of imitations, which became an interesting and peculiar literary phenomenon under the generalized name Kotlyarevschyna (P. Biletsky-Nosenko, P. Korenytsky, K. Puzyna, etc.). The main function of Kotlyarevschyna was the unmasked delimitation of the Russian literature through the choice of a specific language code ${ }^{19}$.

18 Джуанышбеков Н. Типологические группы интеграционной литературы // Літературна компаративістика. Вип. ІІІ. Ч. І. Київ : Стилос, 2008. С. 45-46.

19 Грабович Гр. Семантика котляревщини // Гр. Грабович. До історії української літератури: Дослідження, есе, полеміка. Київ : Основи, 1997. С. 321. 
The second - differential - group is represented by bilingual creativity of writers representing national originality (Levko Borovikovsky, Taras Shevchenko, Grygoriy Kvitka-Osnovyanenko, Panteleymon Kulish, Markiyan Shashkevich, Mykola Ustyianovich, Oleksa Storozhenko, Marko Vovchok and others). The foreign-language part of their creative writing is often not as representative as the Ukrainian-language pieces of fiction.

T. Shevchenko's poetic works, promoting the idea of national revival, at the same time outlined fundamental ways to preserve and develop Ukrainian identity. In his anti-imperial poem "Velykyi L'okh" ("The Great Cellar") the poet called for a struggle against the Russian occupation and expressed a prophetic hope for the revival of Ukraine ${ }^{20}$. According to many literary critics, Shevchenko's Russian-language prose is less aesthetically valuable. It happened, according to Ivan Dzyuba, because of the implicit orientation of the stories to the Russian reader (the reason for the transition to Russian, according to many researchers, was the simple desire to receive a fee for publication in fiction magazines), to which the writer tries to show the true identity of Ukraine - its language, history and culture. However, even lagging behind literary fashion (sic!) and the forced "excommunication" from the then Russian canon did not destroy the original world of the poet Shevchenko in his new role as a prose writer ${ }^{21}$. It should be noted that the issue of Russian-language prose by T. Shevchenko is not limited to the conjuncture or a certain orientation to the literary taste - it is first and foremost an interesting author project that demonstrates the hidden game of an experienced writer with a reader.

The group also includes the artistic achievements of the well-known founder of Ukrainian-language prose G. Kvitka-Osnovyanenko, whose works trace the evolution from classicism and sentimentalism to preromanticism and realism. It is the Ukrainian-language and Russianlanguage prose of the writer that has become to some extent a utopian project, since it creates a mythologized history of everyday life in Sloboda

${ }^{20}$ Шкандрій М. В обіймах імперії: російська і українська літератури новітньої доби / [пер. П. Таращук]. Київ : Факт, 2004. С. 233-236.

21 Дзюба I. М. Тарас Шевченко. Життя і творчість. 2-ге вид., доопрац. Київ : Києво-Могилянська академія, 2008. С. 469-472. 
Ukraine (Slobozhanshchyna, Slobidska Ukrayina) ${ }^{22}$ of the 18th - the $1^{\text {st }}$ half of the 19th cent. In his Ukrainian-language stories the center of the province sometimes even acquires sacred features. In my opinion, it is worth quoting the description of Kharkov - a provincial city, a kind of "capital" of Slobozhanshchyna - from one of his stories:

A good city of Kharkov, big, cheerful; there are lots of the churches of God, the lords' mansions, state residences; there are many houses, the schools of every kind - both for young lords and for young ladies, - the holy father lord's dwelling, the post office, the prison castle - o my father, there are every type of houses in it! Nice and big ones and each is built from stone, and their tops are painted with green paint ... Or a bell tower in the city... If you want to see the top of it, first put your hat on, and then raise your head, fix your eyes on until you see its top with the holy cross; and be attentive, though the hat will not blow off, but you will probably stagger: such high our bell tower is. And how many streets in Kharkov, oh my father! Long and straight are they, and there are some paving ones also: so you don't have to be afraid to cart when it is very bad weather - you will not get stuck in the mud, even if you have got really bad oxen ${ }^{23}$.

In one of his historical essays written on the slope of the age, G. Kvitka-Osnovyanenko narrates a family legend about how Kharkov was founded by his ancestors - sons of a Moscow boyar. As Olexander Borzenko comments, such retelling had a twofold purpose: to justify claims for a privileged place among the nobility of Sloboda Ukraine and emphasize the longstanding connection with the Moscow noble families ${ }^{24}$. Thus, a descendant of the ancient Cossack family makes an attempt to explain their own bizarre combination of local patriotism and devotion to the Russian empire. Even his Russian-language prose and author's translating, often criticized by his contemporaries for the "style difficulty", became a representation (albeit often sentimental) of the Ukrainian

${ }^{22}$ A historical region, now located in North-Eastern Ukraine and South-Western part of the Russian Federation.

${ }^{23}$ Квітка-Основ'яненко Г.Ф. Зібр. творів у 7-ми т. / [ред. колегія : П. М. Федченко, О.І. Гончар, Б.А. Деркач, С.Д. Зубков, Д. В. Чалий]. Київ : Наук. думка, 1978-1981. Т. 3. 1980. C. 304.

24 Борзенко О.І. Сентиментальна «провінція»: (Нова українська література на етапі становлення). Харків : Харків. націон. ун-т ім. В. Н. Каразіна, 2006. С. 216. 
province and its opposition to the imperial center. Thus, in the novels "Zhizn i pokhozhdenyia Petra Stepanova syna Stolbikova, pomeshchika v trekh namestnichestvakh. Rukopis XVIII veka" ("The Life and Adventures of Petro Stepanov, Son of Stolbikov, a Landowner in Three Governorates. Manuscript of the XVIII century") and "Pan Khalyavsky" images of two Russian capitals - Moscow and St. Petersburg - are ridiculous. Ukrainian nobles - the descendants of the former Cossack nobility, who are the recipients of the customs of the capital - are also parodied. However, everything becomes clear, if one takes into account the conditions in which the writer was forced to create, defending Ukrainian-language literature in its officially authorized provincial version from biased and often chauvinistic attacks of Russian literary critics.

Panteleimon Kulish resorted to writing works in Russian throughout his life, but at the same time fruitfully developed the genre system of Ukrainian literature. In his first historical novel "Mikhailo Charnyshenko ili Malorossyia vosemdesiat let nazad" ("Mykhailo Charnyshenko, or Little Russia Eighty Years Ago") P. Kulish, like Sir Walter Scott in the English literature, started to create his own national myth.

The convergentive group comprises writers who use the foreign language of the metropolis while maintaining a national mentality. M. Gogol's prose on Ukrainian subjects (the collections of short stories "Evenings on a Farm near Dikanka", "Mirgorod"), O. Somov's short stories, Russian-language works by G. Kvitka-Osnovyanenko, Ye. Grebinka (the novella "Nezhenskiy polkovnik Zolotarenko" ("The Nezhen Colonel Zolotarenko"), the novel "Tchaikovsky", the collection of short stories "Rasskazy pyriatintsa" ("The Tales of Pyriatyn's Dweller")) are saturated with national images, stereotypes, attitudes that are a reproduction of the Ukrainian character. This group should not be confused with the "Ukrainian school in the Polish literature", the representatives of which are Polish writers of the 19th cent., who appealed to Ukrainian subjects, but mainly to folklore, historical and landscape themes (Michat Czajkowski, Severyn Goszczyński, Michał Grabowski, Bronisław Zaleski, Antoni Malczewski, Tómasz Padúrra, Juliusz Słowacki, etc.). 
Undoubtedly, M. Gogol is a central figure in the convergentive group. One should also mention the theorist of Russian romanticism O. Somov, the predecessor of M. Gogol in winning St. Petersburg's literary commitment. It was $\mathrm{O}$. Somov who presented to the Russian reader the history and folklore of the Ukrainian people in the form of "little Russian wrecks and fables".

Ye. Grebinka, like O. Somov, wrote pieces of fiction about the Ukrainian past, which fit into the then Russian literature. He is also a representative of the so-called "natural school" - the first stage of the Russian realistic literary direction. It should be noted that the author of Russian-language "physiological essays" - perhaps the main genre of this stage - was also G. Kvitka-Osnovyanenko. Ukrainian writers turned to this genre appropriately - in the wake of literary fashion. Literary critics are inclined to believe that in Russian literature this genre was initiated by the authors of the almanac "Our People, Written from Life by the Russians" (1840-1842) edited by Alexander Bashutsky ${ }^{25}$. The writers did not simply "monkey" French or English prototypes, but tried to develop their own concept of depicting life realities, based on the tradition laid down by ethnographic essays by Konstantin Batiushkov, Vladimir Odoevsky and others. However, works that can be attributed to the "physiological essay", appeared earlier - this is, in particular, an essay "The Fair" by G. KvitkaOsnovyanenko, published in 1840 in one of the issues of "Sovremennik" ("The Contemporary").

The biliterary group is represented by a number of names: these include the Ukrainians who launched the historical novel genre in the Russian literature ("Ivan Gosnitsky ..." by V. Narizhny, "Khmelnytsky...", "Nalivayko..." by P. Golota, "Fedyusha Motavilsky..." by I. Kulzhinsky and others). The figure of M. Gogol, whose creativity is crucial for the emergence and development of Russian literature, should also be singled out, so it should also be attributed to the biliterary group.

The creativity of V. Narizhny is important above all because the author, unrecognized for his life's work, is the founder of the classic novel

${ }^{25}$ Кулешов В.И. Натуральная школа в русской литературе XIX века. Москва : Просвещение, 1965. С. 121. 
in the Russian literature ${ }^{26}$. Prohibited by the censorship of the writer's life, the satirical novel "Rossiysky Zhilblaz, ili Pokhozhdeniya knyazya Gavrily Simonovicha Chistyakova" ("A Russian Gil Blas, or The Adventures of knyaz Gavril Simonovich Chistyakov") (1814, 1st full edition - 1938) showed a great influence of the West European picaresque novel in the Russian literature and began the transition to a life-describing realism. Most of his works are Ukrainian-themed - a Bildungsroman "Aristion, ili Perevospitaniye" ("Aristion, or Re-education") (1822), "Bursak" ("The Divinity Student") (1824), the novelettes "Dva Ivana, ili Strast k tyazhbam" ("Two Ivans, or the Passion for Litigation") (1825), "Garkusha, malorossiyskiy razboynik" (“Garkusha, the Little Russian robber”) (1825).

M. Gogol is characterized by a double literary affiliation: without him, it is impossible to construct the Russian literary canon, and at the same time its "ejection" from the Ukrainian literature is quite unjustified. This is due, first of all, to the unambiguous linguistic attitude of the author, who, however, could not silence his own national character and ethnicity. It is in the primary consideration of the cultural context, along with factors such as language, subject matter, ethnic origin or attachment to the territory, as George Grabowicz emphasizes ${ }^{27}$. The borderlines of M. Gogol's creativity are to some extent symptomatic and reflect the complexity of the nationalcultural situation of colonized Ukraine within the Russian Empire.

The assimilative group represents those writers who, despite their genetic affiliation to one ethnic group, belong to language characteristics, education, culture and creativity of another ethnic group ${ }^{28}$. These include, first of all, Antony Pogorelsky, Ivan Bogdanovych, Mykola Gnidych (Hnedych) and writers from Ukrainian families who represent the Ukrainian school in Polish Romanticism (Michał Czajkowski).

${ }^{26}$ Манн Ю. У истоков русского романа // В. Т. Нарежный. Сочинения. В 2-х т. Москва : Худож. лит., 1983. Т. 1 : Российский Жилблаз, или Похождения князя Гаврилы Симоновича Чистякова / Вступ. ст., подгот. текста и примеч. Ю. В. Манна. 1983. C. 14.

${ }^{27}$ Грабович Гр. Українсько-російські літературні взаємини в ХІХ ст.: постановка проблеми // Гр. Грабович. До історії української літератури: Дослідження, есе, полеміка. Київ : Основи, 1997. С. 210-211.

28 Джуанышбеков Н. Типологические группы интеграционной литературы // Літературна компаративістика. Вип. ІІІ. Ч. І. Київ : Стилос, 2008. С. 46. 
The grandson of the last Hetman of the Zaporozhian Host Kyrylo Rozumovsky (Kirill Razumovski), Oleksiy Perovsky wrote exclusively in Russian and entered the Russian literature of the 1st half of the 19th century under the pseudonym of Antony Pogorelsky. The writer was a participant of the Arzamas society, a bright recipient of German fantastic prosaic tradition in Russian Romanticism, as well as the author of the novel "Monastyrka" (1830), in which colonial forms of representation of Little Russia and the imperial view of Ukraine in the 1st half of the 19th cent. are visible (more precisely, at that time administrative-territorial entities of the Russian empire - Poltava and Chernihiv provinces) ${ }^{29}$. Antony Pogorelsky "constructed" the identity of the Ukrainian province, giving certain mythological meanings to artistic images. There are special "closed" topoi of the province/city/town/village in the novel. In "Monastyrka" a reader does not find the Ukrainian landscapes, which were the myth basis of "blessed" Little Russia in many works of Ukrainian and Russian writers of the 1 st half of the 19 th cent.

The narrator portrays an unattractive image of Little Russia with its horrible weather, dirty taverns and messy stations where a tired traveller can't finds horses for his cart. In Antony Pogorelsky's novel, the cultural assimilation of the main characters in the educational institutions of the capital of the Russian Empire fundamentally alters their worldviews and cultural values and bears a real threat to the identity of Ukrainians ${ }^{30}$. The disproportionate conditions in which the Ukrainian province and the Russian capital were described in the novel caused the alleged protest. In particular, in his "Essays on the History of New Russian Literature", A. Kirpichnikov mentioned the anonymous letters of Ukrainian readers to the editorial staffs of Russian magazines, which were full of indignation because of slander in relation to Little Russia and biased evaluations of the nobility in "Monastyrka" 31.

${ }^{29}$ Погорельский А. Монастырка // Антоний Погорельский. Двойник: избранные произведения. Киев : Дніпро, 1990. С. 148-323.

30 Чик Д. Форми протиставлення «центру» і «периферії» у романі «Монастырка» Антонія Погорєльського // Studia methodologica. 2011. № 32. С. 223-225.

31 Кирпичников А. И. Антоний Погорельский, эпизод с истории русского романтизма // А. И. Кирпичников. Очерки по истории новой русской литературы. 2-е изд., дополн. Москва : Книжное дело, 1903. Т. 1. 1903. С. 116-117. 


\section{CONCLUSIONS}

In the article I attempted to revise the canon of Ukrainian literature of the 1st half of the 19th century in light of recent literature studies. By applying the theory of integrative literature to characterize this period, the canon is proposed to include Ukrainian writers who, for various reasons, wrote their works in the language of the metropolis. It should be emphasized that the creativity of one or another writer often does not fit into any one of the groups identified (in particular, M. Gogol). Applied to the 19th century Ukrainian literature in the context of Ukrainian-Russian discourse, the typology changes its configuration depending on the time periods and dominants of historical, cultural and literary processes.

\section{SUMMARY}

In the research the revision of the Ukrainian literature canon of the 1st half of the 19th century is proposed. The Ukrainian literature of the time period is considered as an integrative one with adaptive, differential, convergentive, biliterary, and assimilative typological groups.

It is proved that the research of the 1 st half of the XIX century literature is impossible without taking into account the complex process of the primary formation of the Ukrainian nation, which took place in the colonial circumstances.

\section{REFERENCES}

1. Александрова Г. Глобалізація і нові стратегії в компаративістиці // Українознавчий альманах. 2013. Вип.11. С. 77-79.

2. Андерсон Б. Уявлені спільноти. Міркування щодо походження й поширення націоналізму. Київ : Критика, 2001. 272 с.

3. Ассман Ян. Культурная память: Письмо, память о прошлом и политическая идентичность в высоких культурах древности / пер. с нем. М. М. Сокольской. Москва : Языки славянской культуры, 2004. 368 c.

4. Берков П. Н. История русской комедии XVIII в. Ленинград : Наука, 1977. 392 с. 
5. Беркофф Дж. Б. Чи існує канон українського літературного Бароко? // Український гуманітарний огляд. 2012. Вип. 16-17. C. 9-54.

6. Білецький О. І. Гоголь і українська література // Гоголь i українська література ХІХ ст. : зб. ст. Київ : Держ. в-во худ. літ., 1954. C. 3-18.

7. Блум Г. Західний канон: книги на тлі епох / пер. 3 англ. під заг. ред. Р. Семківа. Київ : Факт, 2007. 720 с.

8. Борзенко О. I. Сентиментальна “провінція": (Нова українська література на етапі становлення). Харків : Харків. націон. ун-т ім. В. Н. Каразіна, 2006. 322 с.

9. Глотов О. Російська література України: методологія питання // Теорія літератури. Компаративістика. Україністика: зб. наук. праць з нагоди 70-річчя професора Романа Гром'яка // Studia methodologica. 2007. Вип. 19. С. 28-30.

10. Грабович Гр. Семантика котляревщини // Гр. Грабович. До історії української літератури: Дослідження, есе, полеміка. Київ : Основи, 1997. С. 316-332.

11. Грабович Гр. Українсько-російські літературні взаємини в XIX ст.: постановка проблеми // Гр. Грабович. До історії української літератури: Дослідження, есе, полеміка. Київ : Основи, 1997. С. 196-237.

12. Гундорова Т. Микола Гоголь i колоніальний кітч // Гоголезнавчі студії. Ніжин, 2009. Вип. 18. С. 17-40.

13. Джуанышбеков Н. Типологические группы интеграционной литературы // Літературна компаративістика. Вип. III. Ч. І. Київ : Стилос, 2008. С. 39-49.

14. Дзюба I. М. Тарас Шевченко. Життя і творчість. 2-ге вид., доопрац. Київ : Києво-Могилянська академія, 2008. 718 с.

15. Зубков С. Д. Русская проза Г. Ф. Квитки и Е. П. Гребенки в контексте русско-украинских литературных связей. Київ : Наук. думка, 1979. 272 с.

16. Квітка-Основ'яненко Г.Ф. Зібр. творів у 7-ми т. / [ред. колегія : П.М. Федченко, О.І.Гончар, Б. А. Деркач, С. Д. Зубков, Д. В. Чалий]. Київ : Наук. думка, 1978-1981. 
17. Кирпичников А. И. Антоний Погорельский, эпизод с истории русского романтизма // А. И. Кирпичников. Очерки по истории новой русской литературы. 2-е изд., дополн. Москва : Книжное дело, 1903. т. 1. 1903. С. 76-120.

18. Когут 3. Розвиток малоросійської самосвідомості і українське національне будівництво // 3. Когут. Коріння ідентичности. Студії 3 ранньомодерної і модерної історії України. Київ : Критика, 2004. C. 80-101.

19. Костомаров Н. Две русские народности (Письмо к редактору) // Основа. 1861. № 3. С. 33-80.

20. Кулешов В. И. Натуральная школа в русской литературе XIX века. Москва : Просвещение, 1965. 300 с.

21. Манн Ю. У истоков русского романа // В. Т. Нарежный. Сочинения. В 2-х т. Москва : Худож. лит., 1983. Т. 1 : Российский Жилблаз, или Похождения князя Гаврилы Симоновича Чистякова / Вступ. ст., подгот. текста и примеч. Ю. В. Манна. 1983. C. 5-44.

22. Павлишин М. Історія літератури і здоровий глузд // Історії літератури : збірник статей/ упоряд. О. Галета, Є. Гулевич, 3. Рибчинська (Центр гуманітарних досліджень ЛНУ ім. Івана Франка). Київ : Смолоскип ; Львів : Літопис, 2010. С. 1-31.

23. Погорельский А. Монастырка // Антоний Погорельский. Двойник: избранные произведения. Киев : Дніпро, 1990. С. 148-323.

24. Сомов О. О романтической поэзии: опыт в трех статьях. Санкт-Петербург : В Тип. Имп. Воспитательнаго Дома, 1823. 102 с.

25. Чик Д. Форми протиставлення “центру” і “периферії” у романі "Монастырка" Антонія Погорєльського // Studia methodologica. 2011. № 32. C. 222-226.

26. Шалагінов Б. “Фауст” Й. В. Гете як центр новоєвропейського літературного канону // Б. Шалагінов. Класики і романтики: Штудії 3 історії німецької літератури XVIII-XIX століть. Київ : КиєвоМогилянська академія, 2013. С. 47-57. 
27.Шкандрій М. В обіймах імперії: російська і українська літератури новітньої доби / [пер. П. Таращук]. Київ : Факт, 2004. $496 \mathrm{c.}$

28. Юрчук О. У тіні імперії: українська література у світлі постколоніальної теорії : монографія. Київ : Академія, 2013. 224 с.

\section{Information about the author:}

Chyk D. Ch.,

Doctor of Philological Sciences in Comparative Literature, Associate Professor at the Department of Foreign Languages and their Teaching Methods, Taras Shevchenko Regional Humanitarian Pedagogical Academy of Kremenets 1, Litseynyi L. str., Kremenets, Ternopil Region, 47003, Ukraine 